\title{
Energy poverty: conceptualization and its link to exclusion. Brief review for Latin America
}

\author{
Carina Guzowski \\ Maria María Ibañez Martin \\ María Florencia Zabaloy
}

I Departamento de Economía Universidad Nacional del Sur, Bahía Blanca, Buenos Aires, Argentina.

D II Instituto de Investigaciones Económicas y Sociales del Sur (IIESS) UNS CONICET, y Departamento de Economía de la Universidad Nacional del Sur Bahía Blanca, Buenos Aires, Argentina.

${ }^{I I I}$ CONICET - Departamento de Economía Universidad Nacional del Sur, Bahía Blanca, Buenos Aires, Argentina

\begin{abstract}
Energy is a critical input for any socioeconomic system and it has become a central point in sustainable development worldwide. Energy deprivation in its various degrees has given rise to the term Energy Poverty. The deprivations in access and quality of energy services sustained over time are elements that generate social exclusion processes and limit the development of the countries with these characteristics. The aim of this paper is to deepen the conceptual discussion of energy poverty and exclusion and the background regarding its measurement, as well as its link with the Just Energy Transition. Descriptive statistics are explored to assess the situation in the Latin American region. It is concluded that the limitations in access to basic energy services are significant, affecting more severely the population of countries with a low level of output and less socioeconomically favored.
\end{abstract}

Keywords: Energy Poverty; Social exclusion; Sustainable Development; Latin America.

São Paulo. Vol. 24, 2021

Special Issue: Energy territories

DOI: http://dx.doi.org/10.1590/1809-4422asoc20200027r2vu2021L2DE 


\section{Introduction}

Energy is a critical resource in every socio-economic system and a central matter in the sustainable development, due to its environmental impact and its influence in other relevant dimensions of human life (UN-Energy, 2007). This is shown by the initiative "Sustainable Energy for All" (SE4All) and the establishment of Sustainable Development Goals (SDG), promoted by the United Nations Development Program (UNDP). The most related goal with this topic is "Affordable and Clean Energy" to satisfy human basic needs at affordable costs and that includes electricity and appliances such as stoves for cooking. However, being energy poverty a multidimensional phenomenon, it is related to other goals such as Ending Poverty, Good Health and Well-being, Reduce Inequalities, Sustainable Cities and Communities, Climate Action, Terrestrial Ecosystem Life, among others.

Currently, 1,300 million people in the world (17\%) do not have access to electricity and 2,700 million (36\%) depend on the use of biomass energy for cooking. Energy poverty has significant implications over health, economy and the environment. In 2012, 4.3 million of people died prematurely due to air pollution as a result of the use of solid fuels to cook (JACINTO et al., 2018). Energy is considered a social good that enhances well-being (RECALDE; GUZOWSKI, 2016) and its supply is essential to the economic, social and environmental organization and the development and social inclusion processes (ROJAS; IBÁÑ̃Z MARTÍN, 2016).

The economic and environmental aspects of the development are affected by exclusion and inequality, creating costs for those who suffer them and affecting society globally. Progress in the population's living conditions is indispensable to achieve a sustainable economic development. The latter is based on the social, economic and environmental dimensions, highly interrelated: a circle of causality among present deprivations in the three dimensions is verified (MAIDANA et al., 2017).

From that it is inferred that analyzing the energy situation of the population is an essential aspect to explain the excluding processes and the relevant policies to be applied to a specific socioeconomic system. Due to the fact that social progress and development are inevitably linked to the access to energy and the consumption of energy intensively (DAY et al., 2016), the discussion is centered on which the sources for optimal energy are. On that path, Beuermann et al. (2012) y Pereira et al. (2010) claim that reducing poverty and the limitations of the energy services have a substantial impact on the deprivation of other relevant dimensions in the generation of exclusion.

It is in this context that the mitigation policies in the energy sector and the concept of Energy Transition become vitally important. Grübler (2012) highlights that the world must evolve towards the next energy transition, after all the energy systems in their current configuration are not sustainable from an environmental, political and social perspective. It is understood by energy transition every change of the energy system from one state to another at a determined time and space (GRÜBLER, 2012). From this wide view, the concept of Just Energy Transition (JET) emerges: it is that path in which there is a reconciliation between the material needs of the poorest sectors and the goal to achieve the objectives of mitigating climate change (JAKOB; STECKEL, 2016). JET 
ensures environmental sustainability, creates decent employment and works in social inclusion and poverty eradication (Smith, 2017).

In light of the aforementioned, the present work is aimed at conducting a narrative revision of the definition of energy poverty and the diverse indicators used to measure it. Additionally, a descriptive analysis is carried out of the relation between energy poverty and social exclusion and the effect of the phenomenon over the development of the economies. Finally, from an analysis of descriptive statistics and records, the situation of energy poverty in Latin America is analyzed and the results are interpreted in the light of the concept of Just Energy Transition. An approach to the phenomena from an econometric and causal remains pending, for future research.

To that end, this work is organized in the following way. After the introduction, in section II the revision and debate of the concepts of energy poverty and social exclusion are addressed. In section III, the descriptive statistics for Latin America are analyzed. Finally, in section IV, the conclusions and final reflections are presented".

\section{Energy poverty, social exclusion and development: conceptualization and relations}

Analyzing the situation of the population regarding their energy deprivations is an essential aspect to explain the excluding processes and evaluate the relevance of the policies (SCHAUBE et al., 2018). Rojas e Ibáñez Martín (2016, pp.123) define access to energy as "the reach to clean, reliable and affordable energy services to cook and for heating, lighting, communications and productive uses. The lack of access is recognized as energy poverty and the people who suffer it belong to sectors called vulnerable".

From there, it is derived from the relevance of the concept of energy poverty. Although this was promoted in the 80's in England, there is still a debate about its meaning and indicators to measure it (ROMERO et al., 2018). An early contribution to the topic adopts a survival approach and takes the definition proposed by Rowntree (1901) "a home is poor when their income is not enough to meet a series of basic needs essential to keep people's physical efficiency". From this perspective, also adopted by the European Economic and Social Committee (EESC), fuel poverty is defined from the estimation of a poverty line using temperature threshold that guarantees thermal comfort and the percentage of the income dedicated to the expenditure of required fuel to reach such level (GARCÍA OCHOA, 2014). Another approach defines a home as poor if its expenditure on energy services surpasses 10\% of their total income (BOARDMAN, 1991; FOSTER et al., 2000). Heindl (2015) characterizes a home as energy poor if, having deducted the rest of the cost of living, cannot afford the energy requirements. Hills (2012) considers that energy poor is someone whose home has an income below the poverty line and his energy requirements surpass the established monetary threshold.

Some studies (WHYLEY; CALLENDER, 1997; HEALY; CLINCH, 2002), questioned the survival approach about fuel poverty. The criticism is based on the methodological difficulty to obtain accurate data about the housing thermal comfort, the occupancy 
duration of the people who dwell in them and the kind of household income. Broader definitions of energy poverty thus emerge, considering the lack of access to modern and clean sources of energy (UNDP, 2005). Modi et al. (2005) define a home as poor if it cannot get access to basic energy services necessary to fight the condition of poverty. From this perspective, energy and energy services are considered fundamental supplies to the development of personal capabilities.

Another alternative is proposed by Healy y Clinch (2017), in which subjective aspects of the concept of fuel poverty are added. Healy (2004) develops a synthetic index of relative deprivation to measure fuel poverty, composed by three objective and subjective indicators. The former addresses housing conditions and equipment while the latter gets if people experience any kind of deprivation in their energy needs. On this same path, Dehays y Schuschny (2018) proposes a series of indicators to evaluate the degree of social inequality regarding access, use and consumption of energy at home.

From this perspective, energy and energy services are considered as fundamental drivers to the development of secondary capabilities in the proposed scheme by Sen (1979) . Thus, Smith and Seward (2009) classified the capabilities into basic or secondaries, the latter is the precursor to the satisfaction of the former and constitutes the updated mechanisms of capabilities. So, energy poverty is defined as the inability to develop essential capabilities as a direct or indirect consequence of an inefficient access (or lack of) reliable, safe and sustainable energy sources and services (SOVACOOL et al., 2014).

In a recent conceptual development González-Eguino (2015) defines energy poverty from three alternative but complementary approximations. These approximations are focused on the access to energy considering three thresholds: technological, focusing on the access to modern energy services; physical, estimating the minimum consumption of energy related to basic needs; economic, establishing a maximum percentage of the income that would be a reasonable energy expenditure.

According to CAF (2013) energy poverty affects a great number of people and families. The most vulnerable homes in scope of this situation are those with low income together with an additional degree of vulnerability (old age, disability and single-parent). In addition, vulnerable homes are more exposed to deprivations regarding adverse weather (cold, heat, humidity) due to the fact that they have inadequate heating and cooling systems as well as poor insulation.

Energy poor people are not usually known as such. The European Union initiative lists a series of situations that energy poor people mention: inability to pay energy bills and/or debts with the supplier, disconnection or threat of disconnection, heath issues related to poor household conditions and as a result of cold and humidity; households with energy efficiency issues. In Table $\mathrm{N}^{\circ} 1$, the revised approaches to energy poverty are summarized, classifying them according to their scope of analysis. 
Table $\mathrm{N}^{\circ}$ 1: Classification of energy poverty approaches

\begin{tabular}{lll}
\hline Scope of analysis & $\begin{array}{l}\text { Energy poverty: } \\
\text { Conceptualization }\end{array}$ & Main leading authors \\
\hline
\end{tabular}

Related to an insufficient level of in-

Boardman (1991)

come to afford energy expenditure.

CESE

Role of energy expendiIt can include the determination of a line of poverty or threshold based on the determination of energy requirements to keep a given quality of life.

Foster et al. (2000)

Heindl (2015)

Hills (2012)

Rowntree (1901) ture in income

Based on the access to energy servic-

Energy services es, beyond energy expenditure. They acquire a determining role in the Healy y Clinch (2002)

Modi et al. (2005)

Whyley y Callender (1997) new and modern sources of energy.

Objective aspects (regarding housing conditions) and subjective aspects

Perception (how people feel) are combined in the measurement to add perceptions.

Dehays y Schuschny
(2018) Healy (2004)

Healy (2017)

Diverse dimensions are added, such Multidimensional as technological, physical (related to energy consumption) and economic.

Iniciativa de la Unión Europea

González-Eguino (2015)

Source: own elaboration

As it can be observed, as with other phenomena, the approaches have evolved and modified that which is considered relevant. The simplest positions focus on energy spending and its relation to household income. From a wider view, approaches which address the importance to energy service access, an aspect that surpasses energy expenditure, are emerged. On the other hand, there are approaches even more complex that add multiple dimension and relative issues as time and agents' perceptions.

According to Bellver (2015) there are two fundamental consequences of energy poverty: health and social exclusion problems. A number of works focus their efforts on defining social exclusion and finding its determinants. However, as Fabre (2000) asserts, there is no definition universally accepted of this concept. The previous records evidence certain central characteristics of the exclusion phenomenon (ATKINSON; HILLS, 1998; TSAKLOGLOU; PAPADOPOULOS, 2002; CASTELLS, 2004; JIMÉNEZ RAMÍREZ, 2008; IBÁÑEZ MARTIN; LONDON, 2018). Among them, the multidimensionality stands out due to a great number of dimensions which intervene in the generation and 
reproduction of a persistence in the deprivations. The relative character, thus exclusion depends on what it is considered relevant to achieve and equalize at a determined time and population, dynamic, is a process which is developed throughout time. Exclusion implies past, present and future, according to Castells (2004) those who may be judged as excluded might not be it tomorrow, depending on the deprivations or privileges they have in different dimensions. Its condition is of multilevel, as it is not an added concept and can be evaluated on a person, a group of people, and of agency, thus exclusion depends on the interaction between individuals, policies, among other issues. The condition of excluded does not depend on the person himself/herself, but on something or someone who intervenes in the result. The relational characteristic, referring to the social bonds that are seen fragmented in a process of exclusion (TSAKLOGLOU; PAPADOPOULOS, 2002).

Within the background, one of the dissenting points refers to which the relevant dimensions are to explain the process of social exclusion in modern societies, even though the multiplicity of spheres is recognized by all authors (IBÁÑEZ MARTIN; LONDON, 2018). In turn, the relative importance of the dimension is another point of disagreement: a group of authors states that the incidence of the dimensions is egalitarian, another group claims that there is dominance of certain issues in the generation of excluding processes and, finally, others consider that there are dimensions of primary and secondary hierarchy concerning the capabilities that they contribute to develop (BURCHARDT et al.,1999). Finally, there is also disagreement in the treatment of exclusion as a dichotomic phenomenon. A group of authors claims that there is a precise line that separates those excluded, while others consider exclusion a phenomenon with shades or degrees.

Therefore, social exclusion can be defined as the persistence of deprivations in a relevant dimension to the normal development of life in society, at a determined time and space (IBÁÑEZ MARTIN, 2017). The phenomenon can be synthesized in the existence of functioning failures which implies that people who suffer them cannot develop necessary capabilities to choose between different styles of life (SEN, 1999). The intrinsic characteristics of exclusion make it difficult to develop indicators that allow measurement and, as Bauman (2012) claims, must avoid the indefinite multiplication of spheres if a measurement for a highly complex phenomenon is looked for. Most of the works analyze the "traditional" dimensions of the process of exclusion, such as education, work, health condition, among others. However, during the last decades new dimensions (environmental, energetic, self-perception, digital gap, participation) have taken a leading role (IBÁÑEZ MARTIN; LONDON, 2017).

An economy that suffers exclusion will be an economy which presents problems in its functioning. The socially excluded individuals perform in a difunctional way, with hindrances in their capabilities to produce, interchange, relate and make decisions. Inequality and exclusion are social pathologies that place an obstacle in the economic development and growth (RAY, 2002), because they froze the central dynamic of the individual and social development. Both phenomena harm social integrity and break vicious circles of citizenship construction, health systems and education. Thus, social exclusion, understood as the generalization and persistence of vulnerability for a wide range of social groups, 
promotes the search for informal and illegal survival alternatives (VITE PÉREZ, 2011).

This position is shared by Myrdal (1957), who agrees that inequality and exclusion are triggering factors of vicious circles of social development and social decline. On this same path, OAS (2014) proposes to deal with inequality as a variable that impacts on the growth and development, given that it is inadequate to evaluate the processes without understanding the mechanisms that generate them. The observed development in different countries cannot be characterized as inclusive if a great proportion of the population lives in the "fragile middle" - they are neither poor nor excluded, but they do not enjoy social, economic, political or institutional security (op. cit.).

Poverty and exclusion represent a difficulty for economic and environmental dimensions of the development, they do not only involve personal costs for those who suffer them, but also affect society as a whole. Progress in living conditions is essential to achieve a sustained development. This is based on the social, economic and environmental dimensions which are highly interrelated: the deprivation of one of them generates and promotes difficulties in another (GONZÁLEZ-ORTIZ; MORALES-PÉREZ, 2015).

Accordingly, deprivations in the energy dimension can be determining of the process of social exclusion and, thus, a central factor in the degree of development. As it has been mentioned, the environmental dimension and, gradually, the energy dimension have taken central relevance in determining well-being and deprivations of modern population (IBAÑEZ MARTIN; MAIDANA; GUZOWSKI, 2019). In this matter, Tirado Herrero et al. (2016) claim that there are micro and macro effects of energy poverty in the different relevant dimensions.

From a macroeconomic level, tightly related to the aim of this work, different authors have pointed out the existent correlation between human development index (HDI) and levels of energy consumption (Figure $\mathrm{N}^{\circ} 1$ ). For example, Kozulj (2011) finds that in Latin America the greater the consumption of energy (kgeo per person), the larger the degree of human development. In this sense, Gacía Ochoa (2014) claims that overcoming poverty and improving the levels of human development is a goal that has to go hand by hand with the increase in the energy consumption per capita. In addition, universal access to energy is necessary to alleviate poverty, enhance economic prosperity, promote social development and improve human health and well-being (GEA, 2012). Agreeing, Velo García (2005) claims that the existence of a tight relation between access to clean and modern energy sources and the different aspects to human development, which are interrelated generating a vicious circle. Among the positive effects, there is the reduction of energy service costs, relieving financial and human resources, especially women's, for other activities or big spending, such as education, better quality food purchases and the expansion of activities which create income (GEA, 2012).

This way, energy has acquired a key role in the development and, thus, in the actions of global development (WORLD BANK et al, 2019). The main previous record was the addition of energy in the Millennium Goals (MDG) which has been extended over time through their observation of the Sustainable Development Goals (SDG), mentioned previously. By 2030 the world is committed to reach the "access to an affordable, safe, 
sustainable and modern energy for all" (GENERAL ASSEMBLY OF UNITED NATIONS, 2012). From the previous mentioned, it becomes clear that the access to modern sources of energy is an essential requirement to mitigate poverty, promote economic growth, create job opportunities, facilitate social services, improve levels of education for the most vulnerable population and, in general, promote human development.

\section{Latin America and energy poverty}

As it was mentioned at the beginning of this research, energy plays a key role in the process of the development of a country, highlighting the relevance of the coverage of energy services (heating, cooking, lighting, refrigeration). The lack of supply generates direct effects overall economic agents' well-being, but in a greater aspect over those with low income (GUZOWSKI, 2016).

According to GEA (2012), on our planet, one out of seven people do not have access to electricity. In addition, around 2,700 million people depend on traditional biomass (such as wood, coal and agricultural waste, including manure) to cook and heat themselves, and another 400 million cook and heat up with coal. Therefore, around three thousand million people depend on solid fuels to cook and heat up. While this happens around the world, the situation in Latin America shows that, on one side, electric coverage is high (the regional average surpasses $90 \%$ ) but, on the other, there are great differences among countries. Thus, between 35 and 45 million people still do not have access to basic energy services (electricity and modern fuels) needed to overcome poverty condition. In particular, almost $75 \%$ of the poor population and at least the third part of the regional rural population do not have access to energy (CAF, 2013; CEPAL, 2013; REN 21, 2018).

An indicator that allows the analysis of the energy profile of a country is the Energy Trilemma Index, which is a tool developed by the World Energy Council. Through this indicator, a ranking of countries according to their performance in three axes is carried out: energy security, energy equity and environmental sustainability, equally weighted. Regarding social equity, the access (to electricity and clean cooking), the quality of the supply and the affordability and competitiveness are assessed. The three axes constitute the trilemma and the challenge relies on keeping the different dimensions balanced in a transitional context (WEC, 2018). By exploring this indicator for countries in this region, it is claimed that Uruguay, Argentina, Costa Rica and Brazil are among the top 40 positions of the global ranking, mainly due to a good performance in environmental sustainability. However, the region faces challenges related to dependency to hydropower, little diversification of energy sources, inequality in the distribution of income and limited use of net interconnections and infrastructure (WEC, 2019).

When comparing regional access to electricity with global average is analyzed, it is observed that the region has a good performance, that means that the average coverage in Latin American and the Caribbean is high (Figure 1). In particular, the main countries of South America have an average level of coverage greater than the regional average. Additionally, it is observed a growing tendency of coverage over the last 20 years analyzed, 
reaching in every case figures above $95 \%$.

Figure $\mathrm{N}^{\circ} 1$ : Electric coverage - access to electricity (\% of the total population) 110

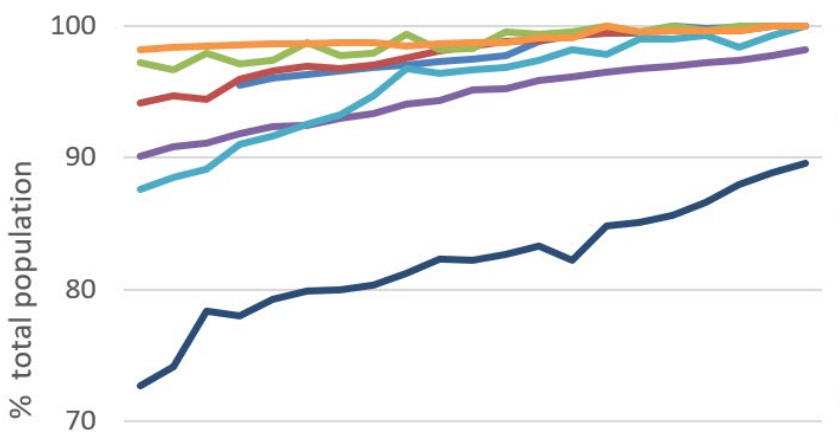

Argentina

Brasil

Chile

América Latina y el Caribe (excluido altos ingresos)

Paraguay

Uruguay

60 $\longrightarrow$ Mundo

50 ๙

Source: Own elaboration based on date from the World Bank

Just as the global level, in the region, the positive relation between the energy consumption per inhabitant and the level of human development is verified (Figure 2). This evidences the key role that energy plays as a social good and as a determinant of the well-being of the population of Latin America. 
Figure $\mathrm{N}^{\circ} 2$ : $\mathrm{HDI}$ and energy consumption per inhabitant: South America

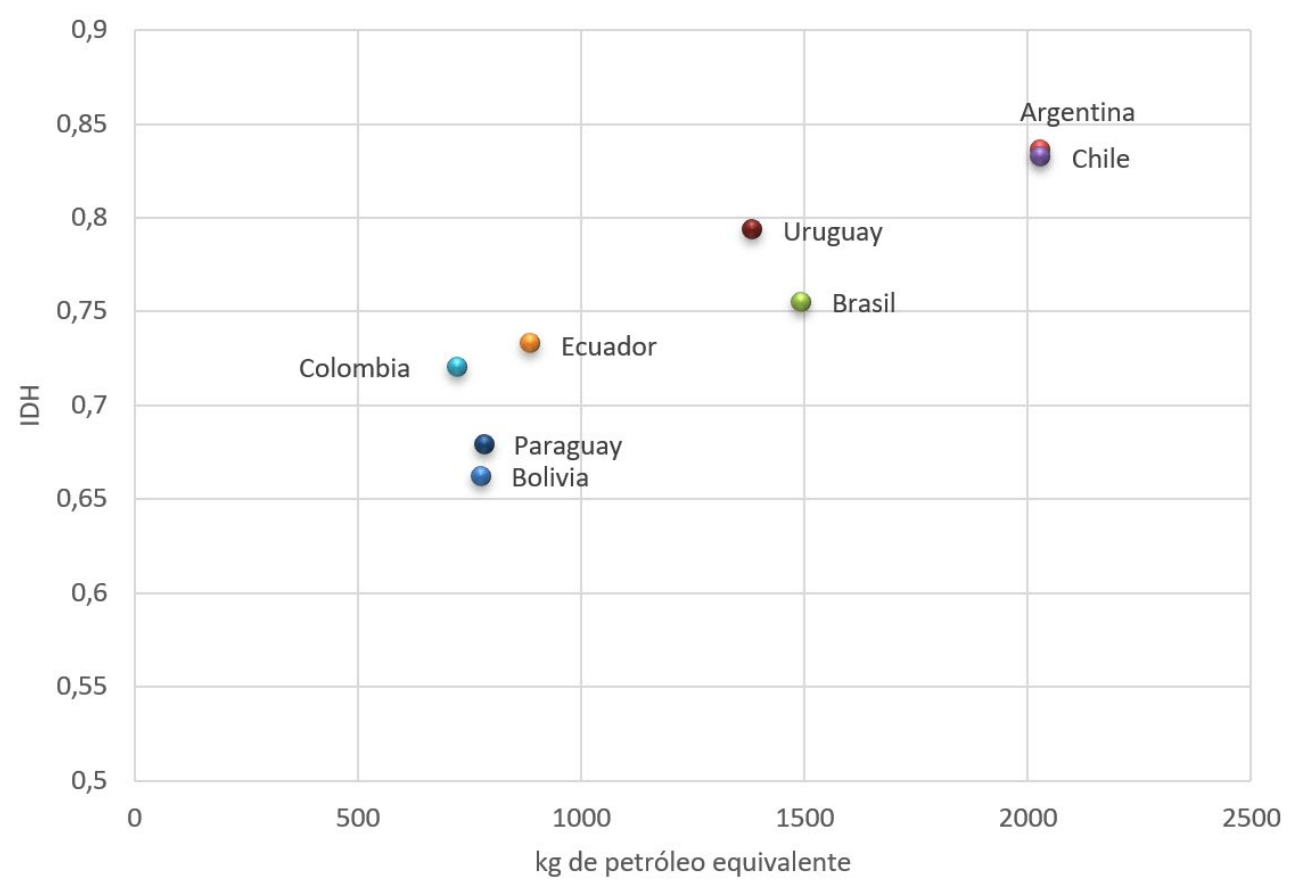

Source: Own elaboration based on data from UNDP and World Bank

Latin America is not the exception, the poor populations are the most affected by energy poverty and the deprivation of access to services and equipment. As it can be observed in Figure 3, according to CEPAL (for its acronym in Spanish) in South America, the electric coverage is a differential factor between richer and poorer populations. Although in South America the access to coverage reaches high levels, within the population that belongs to the lowest quintile in the distribution of income approximately a 10\% does not possess access, while in the last quintile there are no people without access. Additionally, access to equipment is substantially different between quintiles, even though the figure contemplates energy services such as refrigeration and the washing machine (for their sanitary aspect). 
Figure $\mathrm{N}^{\circ}$ 3: Average representation of inequity in the degree of access to equipment according to quintiles of population

Promedio simple 5 paises de América del Sur

Equiparniento quintil 5
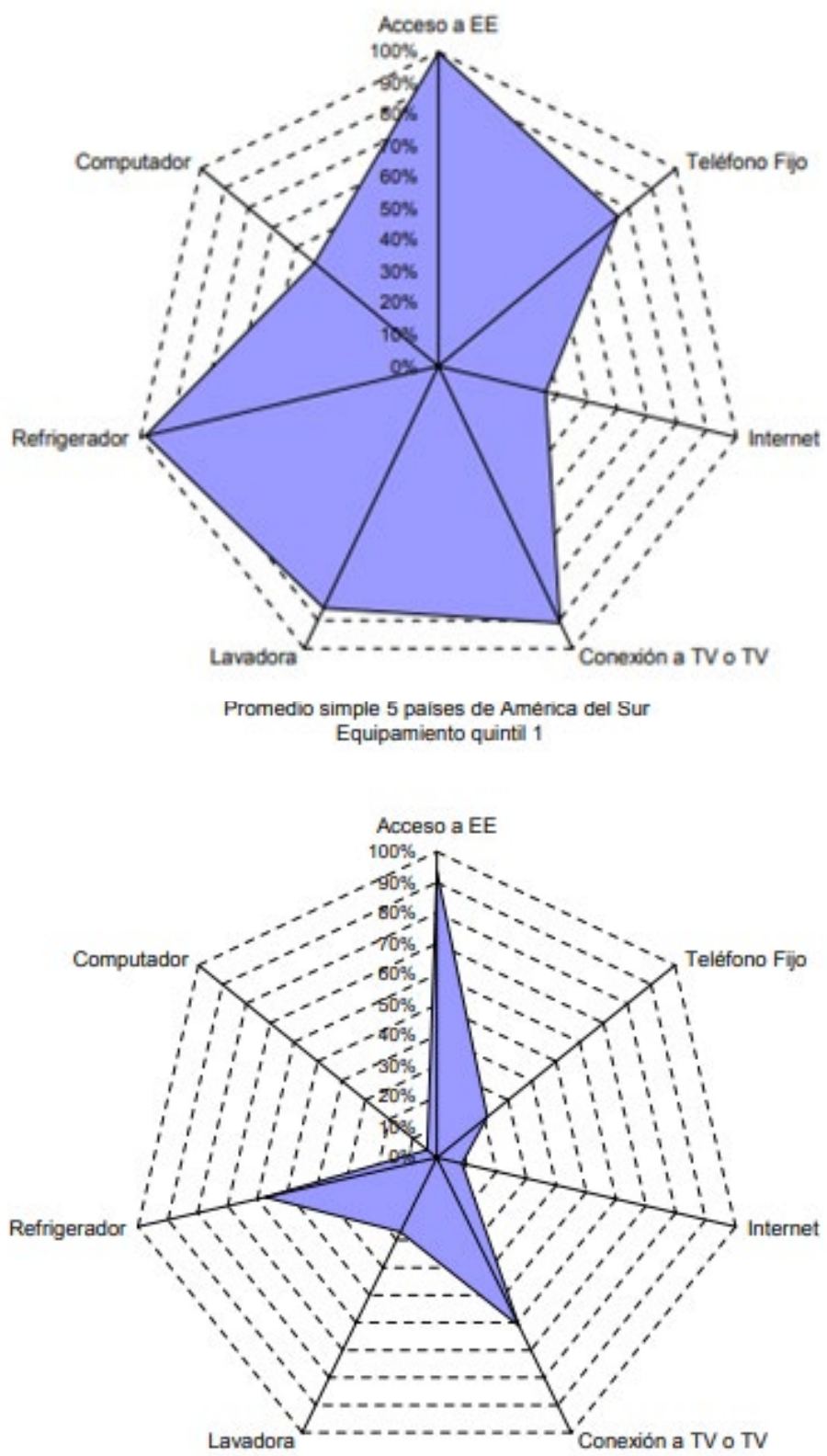

Source: CEPAL, 2009 
When analyzing the total spending devoted to energy service in some countries of the region, a heterogeneous behavior among economies and between poor and no poor populations can be observed (Figure 4)

Figure $\mathrm{N}^{\circ} 4$ : Percentage of the total expenditure in energy services per income quintiles
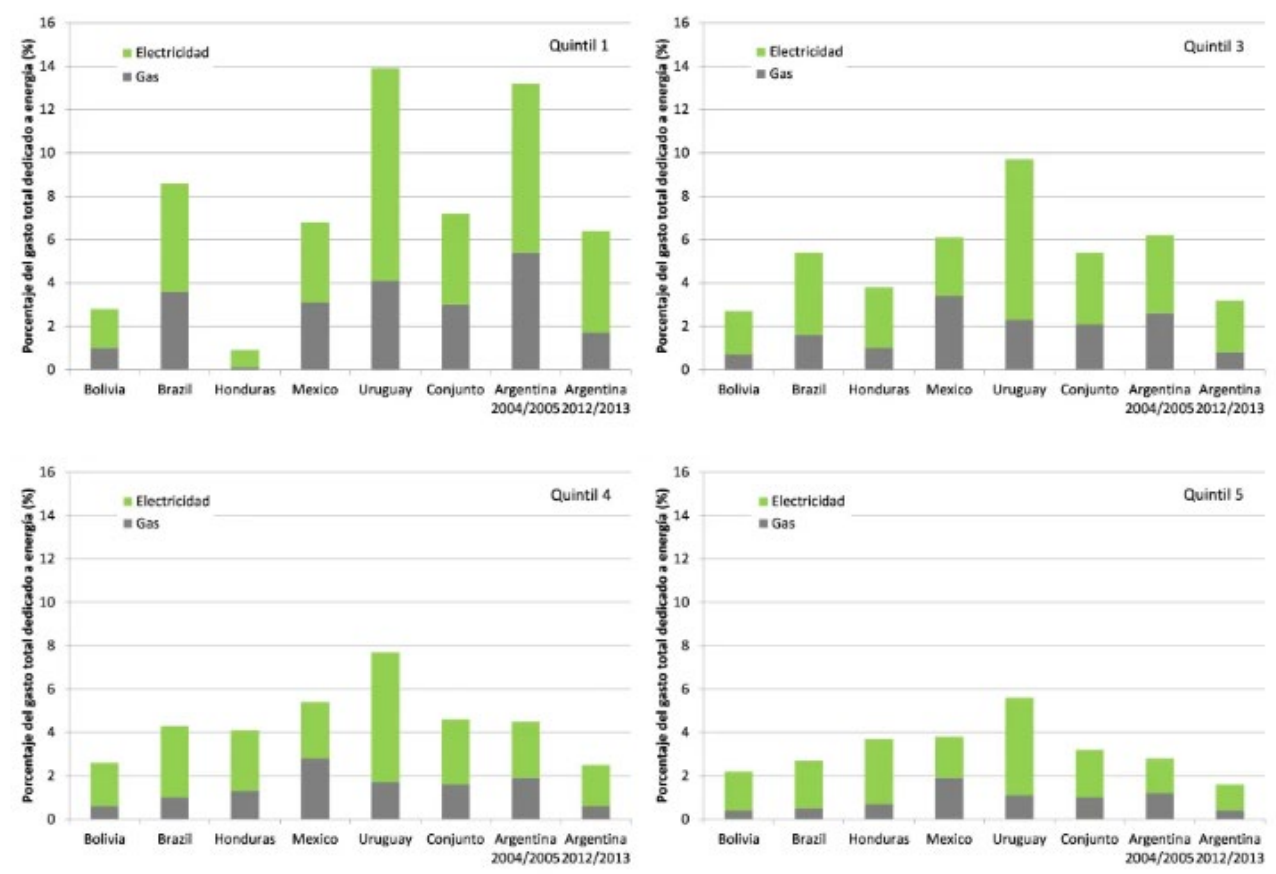

Source: MARGULIS, 2017

In general, in Figure 4, it is observed that in Uruguayan homes, the biggest proportion of their budgets is destined to energy compared to the homes of other countries in the region (14\% of household spending with the lowest income and almost $6 \%$ in those with the highest income). On the contrary, in Bolivia energy access is more equitable (around 2\% of household spending, no matter the level of income). The case of Honduras is striking, due to its antagonistic behavior regarding the rest of the countries analyzed, those with less income devote less than $1 \%$ while those in the richest quintiles must distribute around $4 \%$.

In the particular case of Argentina, it turns out to be interesting to observe the decrease that the energy service spending had between 2004 and 2012, due to (among other factors) National State subsidies. For example, in the year 2004, Argentinian homes were among those that had to devote the greatest percentage of income to energy (especially those with the lowest income). However, in the next decade, they were below the regional average. Thus, in less than 10 years, the proportion of the home budget devoted to gas 
and electricity decreased by half. Also, it is observed that energy has a minor proportion of the families' budget due to the application of a subsidies policy not only in rich families but also in poor ones. Nevertheless, this issue does not indicate anything about inclusion and energy poverty, neither does it indicate anything about the quality and quantity of the energy services that the population has access to.

Additionally, from Margulis' work (2017) it is deduced that Argentina evidences an unequal behavior in the energy spending among the quintiles of the distribution of income, not only between 1 and 5. This behavior is also evidenced in Brazil and Uruguay, while Mexico (extreme cases as in Bolivia) has a steadier behavior among the analyzed quintiles. From here it could be sustained, at least preliminary and acknowledging the need for a deeper analysis, that the richest countries in energy are those which present a more equitable behavior in the spending per home towards energy services.

Furthermore, according to Ibáñez Martín, Zabaloy y Guzowski (2019) deprivations in other relevant dimensions of social life seem to have a relation to the deprivation of energy at home. According to the authors' results, energy poverty (at a severe degree) is evidenced at those homes which verify housing, education, work and health deprivations. The authors conclude that the Independence of energy poverty regarding economic poverty is at least an issue pending investigation.

Even if the poor social classes consume less quantity of energy than the rest of the social classes, they spend a more significant proportion of their income in satisfying such needs. The difficulties to access services through distributions networks of electricity and natural gas and the high costs, drive people in poverty to use wood as basic fuel (CEPAL, 2013). The latter implies a burden for female, children and youth tasks which affect the availability of time for other activities and an unequal access to basic services essential nowadays (preservation of food, Internet, lighting, environment reconditioning, cooking and water use) (CAF, 2013). Also, there are serious consequences in health due to household pollution. Therefore, although it is necessary to guarantee a $100 \%$ of coverage, energy must also be of quality and used efficiently (CEPAL, 2013).

In order to break such vicious circle, it is possible to design energy policies that reduce poverty and allow populations access to modern energy sources, achieve a Just Energy Transition, understanding that the socioeconomic modifications of this kind improve sanitary conditions and can break the trap in which this portion of the population is found (CADENA, 2006). According to Bertinat (2016) the current energy system is not thought to improve life quality of the population and, therefore, it is necessary to provide democratization processes to build another energy reality. In addition, considering justice in the energy transition framework implies building an outlook to energy as a right (BERTINAT, 2016). According to García-García et al. (2020) the central concept of Just Energy Transition is "energy justice", which is separated into: distributive justice, the way in which society shares the positive and negative effects of energy politics, procedural justice, the participation of actor in the process of the development of policy, and recognitional justice, the involvement of limitation to groups negatively affected. As a consequence, the authors define Just Energy Transition as a technological and socio eco- 
nomic process of a structural change in the long time. This process affects the generation, distribution, storage and use of energy, while the wished socioeconomic functions can be fulfilled through decarbonized and renewable means of production and consumption of energy protecting social justice, equity and welfare (GARCÍA-GARCÍA et al., 2020). Therefore, the policies that look for the objective of JET, will make it possible to include traditionally excluded populations, boost the spilling effects of the energy dimension in the rest of the relevant dimensions of the social inclusion processes, a better behavior of the environmental dimension and its correlation with health.

From the formerly mentioned, it is derived that an integral alleviation approach to poverty includes energy as a basic and necessary component rather than a sufficient condition to reach the latter (CAF, 2013). Energy poverty is a present feature in Latin American population, strongly affecting the vulnerable sectors of the population and being different among countries of the region. Thus, due to the relevance of energy as a determinant in other deprivations and social exclusion situations, it is likely that the region presents excluding processes and difficulties to achieve a sustainable and inclusive development.

\section{Conclusions}

The difficulties with energy poverty have increased relevance in political, academic and social discussions lately. The analysis of the situation of the populations regarding this issue has become a fundamental factor due to the central role energy plays as a social good and the determination of human well-being. In addition, energy and other aspects are framed within the environmental dimension of development and are determinants to analyzing the persistence of deprivations and the social exclusion processes.

The definition of energy poverty is not univocal and it is in development depending on the researcher's point of view, the space and time. The most bounded notions of energy poverty referred to the lack of access to limited access to basic energy services. However, just as with the definition of social exclusion, energy poverty is considered a gradient issue for a great group of researchers. Thus, the access, the quality and the quantity of energy services determine the poverty situation in a population. The indicators to measure the importance of the phenomenon have evolved along the last decades and are found strongly linked to information availability. In turn, the progresses and the inclusion of the political science dimension in the generation of indicators about social phenomena (with a strong influence of the "think tanks") in the lead - have generated new discussions.

Energy poverty is considered one of the determining factors in the processes of social exclusion in modern times, for different reasons, but mainly for the positive relation between energy consumption and well-being. Therefore, energy poverty and social exclusion are phenomena that condition and determine the development processes. In particular, energy poverty and the energy consumption present a significant correlation with the index of human development, the economies environmental performance and the development of strategies and policies to diminish the difficulties in the environmental 
and economic dimension of exclusion.

From the revision of the descriptive statistics and previous records concerning the theme, it can be stated preliminarily that energy poverty is a present phenomenon in Latin America. The lack of access or the limited access to basic energy services remains in a no insignificant proportion of the population, it focuses on countries with a lowlevel product and has a substantial presence in poor populations. Energy deprivations are heterogeneous in relation the socioeconomic profile and the geographical location of the population. This situation, that is to say a proportion of population that still presents deprivations in terms of energy, would give a preliminary evidence that the energy transitions experienced (including the current one) can not still be labelled as fair and that this aspect is a pending matter of the energetic, economic and social politics.

It is worth pointing out that the analysis about energy poverty is tightly conditioned by the lack of availability and the lack of depth and regularity of data. The layout of palliative policies about the phenomenon is done under the lack of real knowledge of the problem, in terms of measurement and characterization. This evidences the need to include a specific module in the permanent survey regarding energy services, spending and its consumption.

It is the goal of future researches to deepen the analysis proposed here, break down the results to country level and enquire into the correlation between energy poverty (from its different gradients) and the socioeconomic background which it suffers. At the same time, a future line of research is to build synthetic indicators to measure the degree of the scope of the Just Energy Transition in Latin America, since this concept is strongly linked to energy poverty. 


\section{References}

ASAMBLEA GENERAL DE LAS NACIONES UNIDAS. Energía Sostenible para Todos: un Programa Mundial de Acción. In Sexagésimo séptimo período de sesiones Tema 20 del Programa Provisional de Desarrollo Sostenible. Río de Janeiro: United Nations. 2012.

ATKINSON, A.; HILLS, J. Exclusion, employment and opportunity. LSE STICERD working paper CASE004. p. 1-122. 1998.

BANCO MUNDIAL; AIE; IRENA; UNSD; OMS. Tracking SDG7: The Energy Progress Report. Washington: Banco Mundial. 2019. Available in: https://www.irena.org/publications/2019/ May/Tracking-SDG7-The-Energy-Progress-Report-2019 Access in: 28 April 2020.

BAUMAN, Z. Daños colaterales: desigualdades sociales en la era global. Buenos Aires: Fondo de Cultura Económica. 2012.

BELLVER, J. Controversias en torno a la pobreza energética. Diálogo Entre el Centro de Investigación Econimics for Energy (EfE) Y el Observatorio Critico de La Energía. Papeles de Relaciones Ecosociales y Cambio Global, p. 169-80. 2015.

BERTINAT, P. Transición energética justa: pensando la democratización energética. Montevideo: Fundación Friedrich-Ebert-Stiftung. 2016). Available in: https://tallerecologista.org.ar/wp-content/uploads/2019/02/Doc.-FES-2016.pdf

BEUERMANN, D.; MCKELVEY, C.; VAKIS, R. Mobile Phones and economic development in rural Peru. The journal of development studies, v. 48, n. 11, p. 1617-1628. 2012.

BOARDMAN, B. Fuel poverty: from cold homes to affordable warmth. Michigan: Pinter Pub Limited. 1991.

BURCHARDT, T. LE GRAND, J. ; PIACHAUD, D. Social exclusion in Britain 1991-1995. Social Policy \& Administration, v. 33, n. 3, p. 227-244. 1999.

CADENA, C. ¿Electrificación o energización? Mediante energías alternativas en zonas rurales. Avances en Energías Renovables y Medio Ambiente, v.10, p. 83- 90. 2006.

CAF - CORPORACIÓN ANDINA DE FOMENTO. Energía: Una visión sobre los retos y oportunidades en América Latina y el Caribe. Aspectos sociales del acceso a la energía. México (DF): Banco de Desarrollo de América Latina, p. 1-88. 2013.

CASTELLS, M. La era de la información: economía, sociedad y cultura. Buenos Aires: Siglo XXI. 2004.

CEPAL. Contribución de los servicios energéticos a los objetivos de desarrollo del milenio y a la mitigación de la pobreza en América Latina y el Caribe. Santiago de Chile: CEPAL. 2009.

CEPAL. Desarrollo sostenible en América Latina y el Caribe. Seguimiento de la agenda de las Naciones Unidas para el desarrollo post-2015 y Río+20. Bogotá: CEPAL. 2013. 
DAY, R.; WALLER, G.; SIMCOCK, N. Conceptualising energy use and energy poverty using a capabilities framework. Energy Policy, v. 93, p. 255-264. 2016.

DEHAYS, J.; SCHUSCHNY, A. Una propuesta de indicadores para medir la pobreza energética en América Latina y el Caribe. ENERLAC. Revista de energía de Latinoamérica y el Caribe, v. 2, n. 2, p. 106-124. 2018.

FABRE, M. Consideraciones en torno al concepto de exclusión social. Acciones e investigaciones sociales, v. 11, p.9-22. 2000.

FOSTER, V.; TRE, J.; WODON, Q. Energy Prices, Energy Efficiency and Fuel Poverty, Latin America and Caribbean Regional Studies Program. Washington, D.C.: The World Bank, 2000.

GARCÍA OCHOA, R. Pobreza energética en América Latina. Serie Documentos de Proyecto Cepal, Santiago de Chile: Cepal-Naciones Unidas. 2014.

GARCÍA-GARCÍA, P.; CARPINTERO, Ó.; BUENDÍA, L. Just energy transitions to low carbon economies: A review of the concept and its effects on labour and income. Energy Research \& Social Science, v. 70, p. 101664. 2020. Available in: https://doi.org/10.1016/j.erss.2020.101664

GEA - GLOBAL ENERGY ASSESSMENT. Toward a Sustainable Future. Cambridge, New York, Luxemburgo: Cambridge University Press and the International Institute for Applied Systems Analysis. 2012.

GONZÁLEZ-EGUINO, M. Energy poverty: An overview. Renewable and Sustainable Energy Reviews, v. 47, p. 377-385. 2015.

GONZÁLEZ-ORTIZ, M.; MORALES-PÉREZ, M. El enfoque multidimensional del desarrollo sostenible. Una reflexión necesaria. Santiago, n. 130, p.209-234. 2015.

GRÜBLER, A. Grand Designs: Historical Patterns and Future Scenarios of Energy Technological Change. Historical Case Studies of Energy Technology Innovation En: GRUBLER A.; AGUAYO, F.; GALLAGHER, K.S.; HEKKERT, M.; JIANG, K.; MYTELKA, L.; NEIJ, L.; NEMET, G.; C. WILSON. The Global Energy Assessment. Cambridge: Cambridge University Press, 2012.

GUZOWSKI, C. Los nuevos desafíos de las políticas públicas aplicadas al sistema energético ambiental argentino. In GUZOWSKI, C. (comp.) Los desafíos de la política energética en Argentina. Panorama y propuestas. Buenos Aires: Dunken. 2016.

HEALY, J. D. Housing, fuel poverty and health: a Pan-European analysis. New York: Routledge. 2017.

HEALY, J. D.; CLINCH, J. P. Fuel Poverty in Europe: A Cross Country Analysis Using a New Composite Measurement. Environmental Studies Research Series Working Papers. 2002.

HEALY, J. D. Housing, fuel poverty and health: A pan-European analysis. Londres: Ashgate. 2004. 
HEINDL, P. Measuring fuel poverty: general considerations and application to German household data. FinanzArchiv: Public Finance Analysis, v. 71, p.178-215. 2015.

HILLS, J. Getting the measure of fuel poverty: final report of the Fuel Poverty Review. London: Centre for Analysis of Social Exclusion, London School of Economics and Political Science. 2012.

IBAÑEZ MARTIN, M.M.; MAIDANA, M.F; GUZOWSKI, C. Pobreza energética y exclusión en Argentina: mercados rurales dispersos y el programa PERMER. Revista Reflexiones, v. 99, p. 1-31. 2019.

IBAÑEZ MARTIN, M.M.; ZABALOY, M.F.; GUZOWSKI, C. Una Primera Exploración de la Situación de Pobreza Energética en Argentina: ¿Es la Pobreza Energética un Fenómeno Independiente de las Privaciones Multidimensionales? Anales de la Reunión Anual de la Asociación Argentina de Economía Política. Bahía Blanca, 2019. Available in: https:/aaep.org.ar/anales/ works/works2019/iban\%CC\%83ez.pdf

IBÁÑEZ MARTIN, M. M. Exclusión y desigualdad social: Fenómenos que afectan el desarrollo. Un primer análisis para Argentina. En: CONGRESO NACIONAL DE ESTUDIANTES DE POSGRADO EN ECONOMÍA, VIII, 2017, Bahía Blanca. Actas de congreso. Bahía Blanca: Universidad Nacional del Sur. p.1-29.

IBÁÑNEZ MARTIN, M. M; LONDON, S. Medición de la exclusión social: su relación con la desigualdad y la pobreza. Observaciones para Argentina. En: CONGRESO ALAS, XXXI, 2018, Uruguay. Actas de congreso. Montevideo: Universidad de la República.

JACINTO, G.; CARRIZO, S.; GIL, S. Energía y Pobreza en Argentina. Revista Petrotecnica, n. 3, p. 26-30. 2018.

JAKOB, M.; STECKEL, J.C. The Just Energy Transition. Background Paper for the WWF. 2016. Available in: https://pdfs.semanticscholar.org/3f25/509e25123d2f00bdfc45feb3c5d27dc22c29. pdf?_ga $=2.247729280 .622539162 .1588103569-320391998.1588103569$. Acceso en: 28 abril 2020

JIMÉNEZ RAMÍREZ, M. Aproximación teórica de la exclusión social: complejidad e imprecisión del término. Consecuencias para el ámbito educativo. Estudios pedagógicos, n. 34, p. 173-186. 2008.

KOZULJ, R. Energía y pobreza: un análisis de nexos complejos. Voces en el Fénix, Plan Fénix Facultad de Ciencias Ecómicas de la Universidad de Buenos Aires. 2011. Available in: https:// www.vocesenelfenix.com/content/energ\%C3\%AD-y-pobreza-un-an\%C3\%A1lisis-de-nexos-complejos. Access in: 20 April 2020.

LAPARRA, M.; PÉREZ ERANSUS, B.; LASHERAS, R. Crisis y fractura social en Europa. Causas y efectos en España. Barcelona: Obra Social la Caixa. 2012.

LIDDELL, C. Fuel poverty comes of age: Commemorating 21 years of research and policy. Energy Policy, n. 49, p. 2-5. 2012. 
MAIDANA, M.F.; GUZOWSKI, C.; IBÁÑEZ M.M. Acceso energético e Inclusión social en Argentina: el programa PERMER. En: CONGRESO INTERNACIONAL AGUAS, AMBIENTE Y ENERGÍA, octubre de 2017, Mendoza. Actas de congreso. Mendoza: Universidad Nacional de Cuyo.

MARGULIS, D. ¿Cuánto gastan en energía los hogares en América Latina? Revista Energía Estratégica. 2017. Available in: http://www.economiadelaenergia.com.ar/cuanto-gastan-en-energia-los-hogares-en-america-latina/. Access in: 28 April 2020.

MODI, V.; MCDADE, S.; LALLEMENT, D.; SAGHIR, J. Energy and the Millennium Development Goals. New York: Energy Sector Management Assistance Programme. 2005.

MYRDAL, G. Rich lands and poor: the road to world prosperity. New York: Harper. 1957.

OEA - ORGANIZACIÓN DE LOS ESTADOS DE AMÉRICA. Desigualdad e inclusión social en las Américas: elementos clave, tendencias recientes y caminos hacia el futuro. In Organización de los Estados de América, 14 ensayos. Segunda Edición, p.35-54. San José de Costa Rica: OEA. 2014.

PEREIRA, P.M.; FREITAS, V.; DA SILVA, N. The challenge of energy poverty: Brazilian case study. Energy Policy, v. 39, p. 167-175. 2010.

RAY, D. Economía del desarrollo. Barcelona: Antoni Bosch Editor. 2002.

RECALDE, M.; GUZOWSKI, C. Política Energética y desarrollo socioeconómico: Una aplicación al caso argentino. In: GUZOWSKI, C. (Comp.) Políticas de promoción de las energías renovables: Experiencias en América del Sur. Bahía Blanca: EDIUNS. 2016.

REN 21. Renewable 2018 Global Status Report, Paris: REN21, p. 1-325. 2018.

ROJAS, M.; IBÁÑNEZ MARTÍN, M.M. Planeamiento y gobernanza de las energías renovables para la inclusión social. In: GUZOWSKI, C. IBÁÑEZ MARTÍN, M. Y ROJAS, L. (Comp.) Los desafíos de la política energética en Argentina. Panorama y propuestas. Buenos Aires: Dunken. 2016.

ROMERO, J.; LINARES, P.; LÓPEZ, X. The policy implications of energy poverty indicators. Energy Policy, v. 115, p. 98-108. 2018.

ROWNTREE, B. S. Poverty: A study of town life. Londres: Macmillan. 1901.

SCHAUBE, P.; ORTIZ, W.; RECALDE, M. Status and future dynamics of decentralised renewable energy niche building processes in Argentina. Energy Research \& Social Science, n. 35, p. 57-67. 2018.

SEN, A. The welfare basis of real income comparisons: A survey. Journal of economic Literature, n. 17, p. 1-45. 1979.

SEN, A. Sobre ética y economía. Madrid: Alianza Editorial. 1999. 
SMITH, M.L.; SEWARD, C. The relational ontology of Amartya Sen's capability approach: incorporating social and individual causes. Journal of Human Development and Capabilities, v. 10, p. 213-p235. 2009.

Smith, S. Just Transition a Report for the OECD. 2017. Available in: https://www.oecd.org/environment/cc/g20-climate/collapsecontents/Just-Transition-Centre-report-just-transition.pdf Access in: 20 April 2020.

SOVACOOL, B.K.; SIDORTSOV, R. V.; JONES, B.R. Deciphering energy justice and injustice. In SOVACOOL, B.K.; SIDORTSOV, R. V.; JONES, B.R. Energy Security, Equality and Justice. Abingdon and New York: Routledge. 2014.

TIRADO HERRERO, S.; JIMÉNEZ MENESES, L.; LÓPEZ FERNÁNDEZ, J.L.; PERERO VAN HOVE, E.; IRIGOYEN HIDALGO, V.M.; SAVARY, P. Pobreza, vulnerabilidad y desigualdad energética. Nuevos enfoques de análisis. Madrid: Asociación de Ciencias Ambientales, 2016.

TSAKLOGLOU, P.; PAPADOPOULOS, F. Aggregate level and determining factors of social exclusion in twelve European countries. Journal of European Social Policy, v. 12, n. 3, p. 211-225. 2002.

UN-ENERGY. Energy for Sustainable Development: Policy Options for Africa. Vienna: United Nations. 2007. Available in: https:/open.unido.org/api/documents/4747638/download/Energy\%20for\%20Sustainable\%20Development\%20-\%20Policy\%20Options\%20for\%20Africa. Access in: 28 April 2020.: 28 abril 2020.

UNITED NATIONS DEVELOPMENT PROGRAM. Energizing the Millennium Development Goals. New York: UNDP, 2005.

VELO GARCÍA, E. Desafíos del sector de la energía como impulsor del desarrollo humano. Cuadernos Internacionales de Tecnología para el Desarrollo Humano, n. 5, p. 1-13. 2005.

VITE PÉREZ, V. Sociología y desigualdad social : reflexiones. Intersticios. Revista Sociológica de Pensamiento Crítico, v. 5, n. 1, p. 55-56. 2011.

WEC. World Energy Trilemma Index 2018. Available in: https://www.worldenergy.org/assets/downloads/World-Energy-Trilemma-Index-2018.pdf Access in: 28 April 2020.

WEC. World Energy Trilemma Index 2019. Available in: https://trilemma.worldenergy.org/reports/main/2019/2019\%20Energy\%20Trilemma\%20Index.pdf Access in: 28 April 2020.

WHYLEY, C.; CALLENDER, C. Fuel poverty in Europe: evidence from the European household panel survey. London: Policy Studies Institute, 1997. 


\section{Carina Guzowski}

$\checkmark$ cguzow@criba.edu.ar

ORCiD:https://orcid.org/0000-0002-2745-8332
Submitted on: 28/04/2020

Accepted on: 27/01/2021

2021;24e:00272

\section{María María Ibañez Martín}

$\checkmark$ maria.ibanez@uns.edu.ar

ORCiD: https://orcid.org/0000-0002-0476-1654

\section{María Florencia Zabaloy}

$\square$ florencia.zabaloy@uns.edu.ar

ORCiD: https://orcid.org/0000-0003-0494-1193

How to cite: GUZOWSKI, C.; IBAÑEZ MARTÍN, M. M.; ZABALOY, M. F. Energy Poverty: Conceptualization and its Link to Exclusion. Brief Review for Latin America. Ambiente \& Sociedade. São Paulo, v. 24, p. 1-21, 2021. 


\title{
Pobreza Energética: Conceituação e sua Ligação com a Exclusão. Breve Resenha para a América Latina
}

\author{
Carina Guzowski \\ María María Ibañez Martín \\ María Florencia Zabaloy
}

São Paulo. Vol. 24, 2021

Dossiê Especial:

Territórios de Energia
Resumo: A energia é um insumo crítico de todo sistema econômico social e um ponto central do desenvolvimento sustentável. As privações de energia em seus vários gradientes dão origem ao conceito de Pobreza Energética. Quando as privações se mantêm ao longo do tempo, dão origem a processos de exclusão, constituindo uma limitação para o desenvolvimento das economias que dela sofrem. Este artigo tem como objetivo aprofundar a discussão conceitual sobre a pobreza e exclusão energética e os antecedentes de sua medição, bem como sua vinculação com a Transição Energética Justa. Estatísticas descritivas são exploradas para avaliar a situação na região da América Latina. Conclui-se que as limitações no acesso aos serviços básicos de energia são significativas, afetando de forma mais severa a população de países com baixo nível de produção e menos favorecidos socioeconomicamente

Palavras-chave: Pobreza energética; Exclusão social; Desenvolvimento Sustentável; América Latina.

Como citar: GUZOWSKI, C.; IBAÑEZ MARTÍN, M. M.; ZABALOY, M. F. Pobreza Energética: Conceituação e sua Ligação com a Exclusão. Breve Resenha para a América Latina. Ambiente \& Sociedade. São Paulo, v. 24, p. 1-21, 2021. 


\title{
Pobreza Energética: Conceptualización y su Vínculo con la Exclusión. Breve Revisión para America Latina
}

\author{
Carina Guzowski \\ Maria María Ibañez Martín \\ Maria Florencia Zabaloy
}

São Paulo. Vol. 24, 2021

Dossier especial:

Territórios de Energía
Resumen: La energía es un insumo crítico de todo sistema económico social y un punto central del desarrollo sustentable. Las privaciones en el acceso y calidad de los servicios energéticos se denomina pobreza energética. Cuando las privaciones se sostienen en el tiempo dan lugar a procesos de exclusión, constituyendo un limitante para el desarrollo de las economías que lo padecen. El presente trabajo se propone ahondar en la discusión conceptual de la pobreza y la exclusión energética y los antecedentes de su medición, así como su vínculo con la Transición Energética Justa. Se exploran estadísticas descriptivas para evaluar la situación de la región latinoamericana. Se concluye que las limitaciones en el acceso a servicios energéticos básicos son significativas, afectando más severamente a la población de países con bajo nivel de producto y menos favorecida socioeconómicamente.

Palabras-clave: Pobreza energética; Exclusión social; Desarrollo Sostenible; Latinoamérica.

Como citar: GUZOWSKI, C.; IBAÑEZ MARTÍN, M. M.; ZABALOY, M. F. Pobreza Energética: Conceptualización y su Vínculo con la Exclusión. Breve Revisión para America Latina. Ambiente \& Sociedade. São Paulo, v. 24, p. 1-21, 2021.

DOI: http://dx.doi.org/10.1590/1809-4422asoc20200027r2vu2021L2DE 